
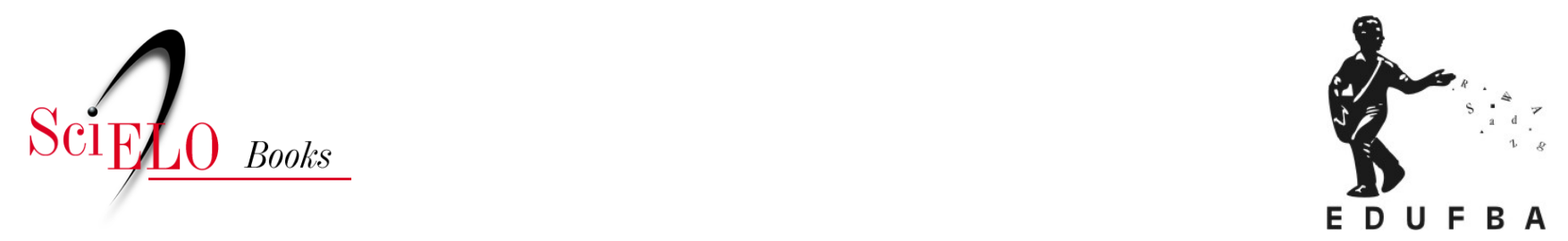

\title{
Imagens do invisível \\ apreensões e representações do sagrado e do espiritual na arte
}

\author{
Genilson Conceição da Silva
}

\section{SciELO Books / SciELO Livros / SciELO Libros}

SILVA, G.C. Imagens do invisível: apreensões e representações do sagrado e do espiritual na arte. In: HERNÁNDEZ, M.H.O., and LINS, E.Á., eds. Iconografia: pesquisa e aplicação em estudos de Artes Visuais, Arquitetura e Design [online]. Salvador: EDUFBA, 2016, pp. 124-137. ISBN: 978-85-2321861-4. https://doi.org/10.7476/9788523218614.0008.

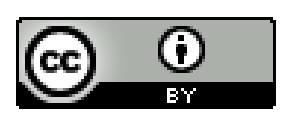

All the contents of this work, except where otherwise noted, is licensed under a Creative Commons Attribution $\underline{4.0 \text { International license. }}$

Todo o conteúdo deste trabalho, exceto quando houver ressalva, é publicado sob a licença $\underline{\text { Creative Commons }}$ Atribição 4.0. 


\section{Imagens do invisível:}

apreensões e

representações

do sagrado e do

espiritual na arte

Genilson Conceição da Silva 


\section{Introdução}

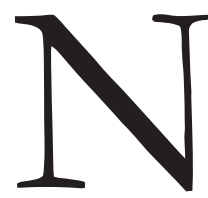

a maioria da arte pré-histórica e antiga, é possível notar a presença de narrativas que evocam experiências com o sagrado, com o transcendente e com o espiritual, bem anteriores às instituições religiosas. Tais características, como sugere Anne Cauquelin (2008), nos remetem ao sentido primitivo do significado da arte, que, por sua vez, não começou certamente como arte pela arte, encontrando-se, no início, a serviço de tendências, dentre elas, um bom número de intenções mágicas.

Registros dessa natureza estão presentes em cavernas, pirâmides, templos, esculturas, dentre outras formas de expressão, nas mais diversas culturas. A experiência mítica e mística se configurou como um alicerce para as primeiras explicações sobre certos fenômenos da natureza que atuavam em nossas relações com o cotidiano: raios, chuvas, nevascas, morte e nascimento.

Longe de ser uma fábula ou algo ficcional, o mito, como diz Eliade (1999), é algo que transcende ao conhecimento racional, existindo como uma verdade maior, além da nossa capacidade de entendimento convencional. A autora reforça ainda que, nos evangelhos e outros testemunhos "primitivos", abundam elementos mitológicos, símbolos, figuras e rituais de origem judaica e mediterrâ- 
nea que foram sendo assimilados pelo Cristianismo. O verdadeiro sentido dessas narrativas está para além da história e revela uma verdade primordial. De acordo com Tomasula (2007), fiéis das três religiões monoteístas encaravam a criação de um mito como um relato simbólico que ajudava as pessoas a se orientarem para questões ontológicas e teológicas, assim como para a condição concreta e presente.

Com a sistematização e evolução do conhecimento científico, livros de tradição religiosa, portadores de histórias míticas, foram objetos de constante historização. A partir do século II, por exemplo, a teologia cristã teve que defender a historicidade de Jesus, no intuito de evidenciar a veracidade dos acontecimentos bíblicos. A despeito disso, muitos religiosos, místicos, escritores, artistas, dentre outros, envolvidos com o tema do sagrado, procuraram se identificar com as dimensões mitológicas e subjetivas expressas nas escrituras sagradas, haja vista que, como afirma Eliade (1999), a perspectiva mitológica amplia o horizonte dos acontecimentos. O mito é entendido por certos eruditos ocidentais atuais como uma história verdadeira e, ademais, extremamente preciosa por seu caráter sagrado, exemplar e significativo.

Para vivenciar os mitos e, dessa forma, acessar o tempo sagrado, se faz necessário atualizar, na vivência cotidiana, a epifania experimentada pelos personagens presentes nas narrativas primordiais. Antes mesmo da invenção da escrita, isto era feito pela cultura oral, pelos rituais, pelas imagens e por certos objetos mágicos. A religião cristã, através da arte, lançou mão dos ícones que eram um dos elos materiais para a realização da experiência transcendental.

Muitos artistas, em diversos períodos da história da arte, se inspiraram no sagrado como tema capaz de apontar para além de uma narrativa literal e óbvia. Eles traduziram em imagens o sentido poético, singular e polissêmico dessas narrativas, inclusive os mitos bíblicos. Os ícones religiosos eram obras que permitiam alcançar o invisível e/ou torná-lo visível, uma forma de exprimir aquilo que nos ultrapassa, o inexprimível, o transcendental. Como afirma Fischer (2007), essa linguagem representa Deus e seus mistérios. Sua função primordial é nos religar aos mitos, àquilo que nos ultrapassa e nos escapa.

Em relação à experiência com o sagrado, o Ocidente teve tanto a religião quanto a arte profundamente influenciadas pela Bíblia, que, por sua vez, é o livro sagrado que mais influenciou e continua influenciando decisivamente vários aspectos da cultura ocidental. A respeito disso, Couto (2007, p. 14) traz a seguinte afirmação:

A Bíblia, livro sagrado do Cristianismo, está dividida em 66 livros, sendo 39 do Velho Testamento e 27 do Novo Testamento. Seu conteúdo é motivo de debate há séculos e mesmo nos dias de hoje suscita novas pesquisas... Trata-se de 
uma obra que transcende o campo religioso. Por exemplo, a noção de que o planeta flutua no espaço (vista em Jô 26:7) é datada de pelo menos 3.200 anos antes de Galileu aparecer em cena. [...] Possui uma beleza poética que inspirou no campo das artes: poetas, escritores, cineastas, pintores, escultores, etc.. Além de outras esferas nos campos sociais, políticos entre outros. [...] Não é a toa que é considerado o livro que mais influenciou a humanidade. [...] Calcula-se que, para sua redação, deve ter sido gasto um período de 1600 anos de trabalho. Foi traduzida para 2.403 idiomas, o que a torna também o livro mais traduzido do mundo.

A despeito das ideologias institucionais religiosas vigentes em cada momento histórico, o primeiro livro impresso por Gutemberg inspirou, através de suas narrativas, artistas de diversas partes, principalmente do mundo ocidental. A narrativa bíblica tomou forma através de imagens; dos mais modestos mosaicos do cristianismo primitivo às grandes catedrais e museus, um monumental conjunto de obras transfiguraram palavras em imagens, compondo uma grande parte dessa história. Sobre esse aspecto, o teólogo alemão e abade primaz dos beneditinos, D. Notker Wolf (2002), em entrevista concedida à Revista Cult, afirma que:

O Cristianismo é a única cultura religiosa que permitiu um desenvolvimento no campo da arte, pois leva a sério o fator tempo e a historicidade no desenvolvimento humano. No islã, a arte permaneceu a mesma, em Meca, Granada, Jacarta e em toda a África. Mesmo no budismo não se vê um desenvolvimento: não se pode a priori distinguir um templo moderno de um templo antigo. O Cristianismo conheceu uma longa história da arte arte romana, carolíngia, românica, gótica, renascentista, barroca etc. O Cristianismo diz sim à temporalidade da história humana, conhece o tempo que se desenvolve. (WOLF, 2002, p. 21)

Em parte significativa dessas obras sacrorreligiosas está presente o binômio matéria-espírito. A arte desenvolveu um vasto conjunto de obras que carregam conceitos e representações que desafiam, até hoje, o nosso olhar, em busca de significados e interpretações possíveis. Mesmo na arte antiga, medieval, renascentista ou barroca de caráter religioso, as imagens narrativas tinham, como um dos principais objetivos, levar o olhar para além das imagens. A mitologia por trás destas foi capturada por um conjunto significativo de esculturas e pinturas que, até hoje, conduzem o olhar do espectador contemporâneo ao invisível para aquilo que as palavras não conseguem capturar. 
Cauquelin (2008) afirma que é necessário renunciar à ideia de uma separação entre espírito e matéria, visível e invisível e, paralelamente, à ideia de uma equivalência entre invisibilidade e imaterialidade, assim como entre imaterialidade e espiritualidade. Pode-se notar, como veremos a seguir, o quanto a arte sacrorreligiosa aproximou essas dicotomias e, de certa forma, o quanto artistas modernos e contemporâneos que abordam tais questões tentaram romper tais dicotomias através de obras que não necessariamente representam a religiosidade, mas contemplam, através de suas imagens, a busca pelo transcendente. Utilizando materiais e técnicas das mais diversas, esses artistas continuam sua busca pela apreensão do invisível. Nesse sentido, Walter Benjamin (1992, p.70), em seu livro Sobre arte, técnica, linguagem e politica, traz o seguinte:

As mais antigas obras de arte, como sabemos, surgiram a serviço de um ritual, inicialmente mágico, e depois religioso. O que é de importância decisiva é que esse modo de ser aurático da obra de arte nunca se destaca completamente de sua função ritual. Em outras palavras: o valor único da obra de arte 'autentica' tem sempre um fundamento teológico, por mais remoto que seja: ele pode ser reconhecido, como ritual secularizado, mesmo nas formas mais profanas do culto do Belo.

O artista, segundo Besançon (1997), é o sacerdote e o teólogo, e sua obra é o sacramento dessa mediação. Uma vez que a verdadeira essência do homem está em sua alma imaterial, cabe ao artista a tarefa de dar forma ao que não tem, proporcionar uma equivalência formal ao informal. Ele faz uma instigante analogia:

A imagem de Deus no homem é como uma placa fotográfica impressionada, mas sem passar pelo processo de revelação, e que a encarnação do verbo vai 'revelar'. Pois como assinala Irineu, o Cristo é o visível do Pai, e o Pai o invisível do Cristo. (BESANÇON, 1997, p. 67)

De certa forma, compreender a natureza de cada imagem que nos separa de Deus e que dele nos aproxima na qualidade de vestígio e signo equivale também a determinar o sentido do mundo visível e da visão do homem. O que nos remete à frase de São Paulo: "Vemos agora através de um espelho como um enigma, mas quando vier o que é perfeito veremos face a face”. (CORÍNTIOS 13: 12 apud BESANÇON, 1997)

João Damasceno (730 apud BESANÇON, 1997), autor da primeira síntese teológica do ícone, também traz a relação entre material e imaterial. Segundo ele, a matéria nos conduz ao Deus imaterial, fazendo-nos remontar, se assim se pode dizer, à corrente descendente pela qual Ele conduziu a energia divina. Damasceno considera que precisamos das coisas corpóreas como intermediárias para que 
conduzam às coisas inteligíveis. Ele esforça-se em demonstrar que a matéria é capaz de nos levar às realidades inteligíveis. O autor prossegue afirmando: "Não venero a matéria, mas o criador da matéria que se fez matéria para mim e que dignou habitar a matéria e realizar minha salvação pela matéria. Não cessarei de venerar a matéria por meio da qual me adveio a salvação”. (DAMASCENO, 730 apud BESANÇON, 1997, p. 287)

A relação entre o material e o imaterial é justamente uma das premissas dos ícones religiosos, objetos que conectam o mundo físico ao mundo espiritual. Frequentemente, o ícone é translúcido, como se os personagens representados fossem penetrados por uma luz misteriosa. Para Burckhardt (2004), na composição de um ícone, essa iluminação não é direcionada. Em compensação, o fundo dourado é chamado "luz", pois corresponde à luz celestial de um mundo transfigurado.

Constantino V vai mais longe ao afirmar que "o ícone circunscreve, sim, o Verbo de Deus, mas foi Deus quem começou, pois circunscreveu-se a si próprio tornando-se homem, e bem mais que isto: um indivíduo". (CONSTANTINO apud BESANÇON, 1997) Os artistas que produziam ícones sacros transformavam o ato de pintar numa espécie de rito.

A produção de ícones religiosos era considerada uma arte nobre, que necessitava grande preparação técnica e espiritual do artista e dos materiais envolvidos. O pintor precisava se purificar de corpo e alma para conseguir a perfeição, achava-se que o divino operava pela mão do pintor, então era inoportuno assinar a obra. (BURKE, 2004, p. 58)

Dessa forma, o próprio pintor estava imbuído das duas naturezas, divina e humana. $\mathrm{O}$ ato de pintar já era poético em si mesmo, pois, para trazer ao mundo imagens que conectavam a matéria ao espírito, o artista executava uma espécie de performance-ritual.

Parece até evidente que toda a arte seja movida pelo desejo de encontrar o invisível e de mostrá-lo, como se o artista tivesse, de forma inata, o dom (e o dever) de abrir a obra para o mundo da mística, ou ainda mais simplesmente, 'de abrir um mundo'. Desse modo, vemos objetos distintos, de contornos definidos. Aquilo que é distinguido, circunscrito, é também o que chamamos de visível. O que é visível tem uma forma e nós percebemos um objeto na medida em que ele tem uma forma. O informe e o indistinto nos escapam. Poderíamos dizer, então, que o invisível é aquilo que não tem forma, que é indistinto, não separado. A caça ao invisível, à qual tantos artistas parecem se dedicar, seria uma 
tentativa de dar uma forma àquilo que não tem forma, ou de fazer sair algo de indistinto do domínio para disponibilizá-lo para o nosso mundo, para pô-lo ao alcance da visão. (CAUQUELIN, 2008, p. 146)

A luz é constantemente evocada nos ícones e nas obras de caráter sacrorreligioso como forma de representar o divino, o invisível, ou mesmo de servir como um elo entre o mundo material e o mundo espiritual. Não por acaso isso acontece, pois, como afirma Susin (2003), a palavra "Deus" é de origem sânscrita," indo-europeia, e significa "luz", sendo esta, de fato, uma poderosa e complexa metáfora do divino. Com efeito, a palavra luz na Bíblia ocorre diversas vezes para descrever a divindade. Em outras religiões, inclusive, no Oriente, é muito frequente também essa identificação da divindade com a luz, a exemplo do Sol, que foi um dos primeiros elementos mitificados pelo homem. Em algumas culturas, o homem se considerava filho do Sol, a exemplo dos incas. Adorar o Sol tornou-se parte da civilização. A maioria dos templos gregos foi orientada para o leste, de modo que a luz do Sol nascente, através das portas de entrada, iluminasse as estátuas internas.

O Midrash, ${ }^{2}$ um dos livros sagrados do judaísmo, contém muitas afirmações acerca do Espírito Santo, dentre elas, a que diz que o Espírito Santo, sendo de origem celeste, é composto, como tudo aquilo que vem do céu, de luz e de fogo. Já a cabala luriânica ${ }^{3}$ traz o seguinte:

O primeiro ato de Deus não foi um passo para fora, mas para dentro, foi um exílio de Deus dentro dele mesmo. No vácuo criado, Deus lançou um raio de luz que foi conduzido por vasos. Mas à medida que a criação prosseguia, alguns vasos não resistiram a força da luz e a maior parte da luz voltou para a sua fonte infinita, mas o restante das centelhas ficaram presas ao mundo material, portanto, a tarefa do ser humano é libertar a sua centelha para restituí-la à divindade. (SANTIAGO-RAMOS, 2009, p. 68)

\footnotetext{
1 A língua sânscrita, ou simplesmente sânscrito, é uma língua da Índia, com uso litúrgico. É uma das línguas mais antigas da família indo-europeia. Sua posição nas culturas do sul e sudeste asiático é comparável ao latim e ao grego na Europa, e foi uma protolíngua, pois influenciou diversas outras línguas modernas.

2 Midrash é uma forma narrativa criada por volta do século I a.C. em Israel, pelo povo judeu. Essa forma narrativa desenvolveu-se através da tradição oral até ter a sua primeira compilação apenas por volta do ano 500 d.C.

3 Sistema Cabalístico desenvolvido por Isaac Luria, conhecido estudioso e místico judeu, fundador de uma das ramificações mais importantes da cabala.
} 
Ou seja, na tradição judaica, da qual o Cristianismo derivou e onde boa parte da Bíblia está alicerçada, principalmente o Velho Testamento, a divindade também era identificada com a luz, reiterando o legado de antigas tradições e culturas.

No Evangelho segundo João, ele afirma: "E esta é a mensagem que dele ouvimos e vos anunciamos: que Deus é Luz, e não há nele treva nenhuma”. (JOÃO 1: 5) Nota-se que João não diz que Deus é como a luz, ele afirma que a Luz é a própria divindade. Numa outra passagem, ainda segundo João, o próprio Cristo disse: "Eu sou a luz do mundo; quem me segue de modo algum andará em trevas, mas terá a luz da vida". (JOÃO 8: 12)

Por sua vez, a luz é a alma do ícone. Segundo alguns filósofos gregos, o olho e o objeto emitiam igualmente luz, e a visão se produzia quando era formado um meio luminoso homogêneo entre o olho e o objeto. Mas com Platão e, sobretudo, com Plotino, a luz comunica beleza e bondade às coisas, razão pela qual a oposição luz-treva substitui a oposição clássica entre ordem e desordem. Como afirma Besançon (1997, p. 315), "[...] a luz arranca a matéria da sua natureza tenebrosa. Mas a luz material, natural e criada converte-se, ela própria, em trevas, se comparada com a luz inteligível e incriada que se irradia do Deus incognoscível". Essa reviravolta, que transforma em trevas supraluminosas a luz material criada, é explicitada nos ícones da transfiguração.

Os Ícones da Transfiguração retratam a passagem bíblica presente em Mateus (17: 1-13), que descreve o momento em que Jesus sobe a um alto monte com três discípulos, João, Pedro e Tiago, e lá eles assistem à sua transfiguração. Segundo o relato, seu rosto resplandeceu como o Sol e suas vestes se tornaram brancas como a luz. Ao centro, domina a figura do Cristo em vestes brancas; raios de luz se desprendem da sua pessoa e se espalham em todas as direções rumo à extremidade de um círculo, símbolo da verdade. Ele está no alto de um monte e, ao seu lado, sobre dois picos rochosos, veem-se as figuras de Moisés e Elias, profetas do Antigo Testamento, ligeiramente inclinados para o Cristo, com o qual conversam. Embaixo, a cena apresenta figuras do Novo Testamento: os três discípulos escolhidos para subir ao monte estão em atitude de grande espanto. À direita (de quem olha), Pedro, de joelhos, com uma das mãos se apoia no chão e, com a outra, aponta para o divino fulgor; Tiago e João estão caídos no chão e cobrem os olhos ofuscados pela luminosa teofania. ${ }^{4}$ A fraqueza humana perante o evento excepcional, por contraste, ressalta a paz transcendente e a divina segurança de Jesus, centro de tudo.

A luz não serve para modelar o contorno e os relevos, ela não está encarregada de sugerir a ilusão. Ela irradia da própria imagem para o espectador. Os corpos

4 É um conceito, de cunho teológico, que significa a manifestação de Deus em algum lugar, coisa ou pessoa. 
do ícone, segundo Burckhardt (2004), não se banham numa iluminação cuja fonte seja-lhes exterior. Eles trazem uma luz própria.

Recorrendo à narrativa da transfiguração, Artur Danto (2005), em seu livro A transfiguração do lugar comum, observa a possibilidade da arte contemporânea em transformar objetos e experiências ordinárias em extraordinárias, elevando-os ao status de arte. $\mathrm{Na}$ arte contemporânea, o tema do espiritual levou grande parte dos artistas voltados para esta finalidade a transfigurar a luz icônica em obras polissêmicas, na busca irreligiosa do sagrado. Dessa forma, objetos, materiais e procedimentos dos mais diversos, em diferentes linguagens, são utilizados na tentativa de captura do invisível. De certa forma, esses artistas continuam sua busca pelo espiritual, na tentativa de uma afirmação visível do invisível.

\section{Narrativas poéticas do sagrado na arte contemporânea}

Se, no passado, os artistas ilustravam as narrativas bíblicas, hoje eles traduzem essa narrativa a partir de uma leitura mais pessoal. Em alguns casos, os temas sacros aparecem revisitados por um olhar mais conotativo e, muitas vezes, abstrato. A seguir, alguns trabalhos que dialogam direta ou indiretamente com a narrativa bíblica.

O pintor Barnett Newman elaborou uma série de pinturas denominadas Zip, também conhecida como Tiras de Luz, que evocam metáforas presentes na tradição literária do Gênesis, através da luz como símbolo da criação - onde Deus e o homem aparecem constituindo um único emissor de luz. O criador e a criatura formando uma só unidade sublime, como afirma Amaral (2007). "É com esse sentimento de sublime, daquilo que é irrepresentável no caso, a relação com o absoluto que Newman apresenta suas pinturas de características abstratas". (AMARAL, 2007, p. 206) Segundo ele, esse é o único modo de focalizar os mistérios da criação. Sendo assim, a série de pinturas Tiras de Luz, de Newman, evocam, tanto conceitualmente quanto em nível de procedimento adotado em sua pintura, o componente imaterial da luz.

Já a artista gaúcha Karin Lambrecht utiliza o sangue de carneiros abatidos para narrar poeticamente a genealogia de Cristo, recorrente na Bíblia. A proposta de trabalho de Lambrecht partiu de uma viagem de cinco dias por Israel, onde visitou dois abatedouros de carne ovina. O resultado dessa imersão é a obra Pai, que remonta às origens da genealogia de Jesus Cristo. Em uma estrutura de 10 metros de comprimento, 77 lâminas de acrílico emolduram 77 pequenas cruzes, banhadas na lavagem do sangue de carneiros, abatidos em solo israelense, acompanhadas de caligrafias que replicam as 77 gerações da genealogia de Jesus Cristo, segundo o Evangelho de São Lucas. 
Os trabalhos de Karin Lambrecht parecem não apenas relacionar-se com a arte, mas dispor dela para relacionar-se diretamente com a vida; para acionar ligações do indivíduo consigo mesmo - com o seu corpo, sua história, sua memória, com uma zona obscura de seu pensamento - e com o outro - nos embates entre o humano e a força bruta da natureza, nas trocas de suas energias, como também pelo advento transcendente. (AMARAL, 2007, p. 216)

Temas como destruição, recriação, agitação violenta e renovação espiritual são recorrentes na obra do alemão Anselm Kiefer. Sua obra Palmsonntag é uma instalação composta por pinturas realizadas pelo artista, ao longo de 18 anos, penduradas como uma única entidade em uma parede, com uma palmeira de 13 metros sobre o chão da galeria. A obra evoca o início da jornada de Cristo em Jerusalém, antes de sua prisão, paixão, morte e ressurreição.

Como é comum na prática de Kiefer, materiais orgânicos formam paisagens poéticas, resultando em trabalhos que não apontam para uma única interpretação. Eles sugerem uma multiplicidade de sentidos: "Domingo de Ramos tem um lugar central na teologia cristã, mas raramente tem sido objecto de pinturas mais importantes", diz Kiefer. (apud SANTIAGO-RAMOS, 2009, p. 274) Em seus trabalhos, ele adiciona uma dimensão que inclui mitologia, história e alquimia da mitologia greco-romana, do antigo gnosticismo e do misticismo cabalístico.

Numa tradução poética, unindo arte, ciência e tecnologia, Eduardo Kac cria sua obra Gênesis. No procedimento desse trabalho, ele traduziu para o código Morse $^{5}$ o seguinte trecho bíblico, pertencente ao livro de Gênesis: "Que o homem tenha domínio sobre os peixes do mar e sobre as aves do céu e sobre cada ser vivo que se mova sobre a terra". (GÊNESIS, 1:26) Após traduzir a sentença para pontos e traços do código Morse, o artista adotou a seguinte convenção criada por ele: os pontos foram substituídos pela base genética ${ }^{6}$ citosina (C), os traços por timina $(\mathrm{T})$, os espaços entre palavras por adenina $(\mathrm{A})$, e os espaços entre letras por guanina (G). Segundo Tomasula (2007), essa cadeia única de AGCTs constitui um gene que não existe na natureza, seria, portanto, um "gene da arte".

Após codificado o trecho para as bases protéicas e sintetizado em laboratório, Kac transfere o DNA sintetizado para proteínas fluorescente e, depois, as insere em bactérias de Escherichia Coli. ${ }^{7}$ Através de um microscópio, o espectador pode

5 Sistema de representação de letras, números e sinais de pontuação, através de um sinal codificado, enviado intermitentemente. Foi desenvolvido por Samuel Morse em 1835.

6 Adenina, Citosina, Guanina e Timina são bases nitrogenadas encontradas no DNA.

7 A Escherichia coli é uma bactéria que, juntamente com o Staphylococcus aureus, é a mais comum e uma das mais antigas bactérias simbiontes do homem. 
observar uma placa de petri ${ }^{8}$ onde se encontram as bactérias, ao mesmo tempo em que a imagem é projetada na parede do espaço onde se encontra a obra.

O olhar de Deus, proporcionado por Kac, vem de uma microcâmera. As galáxias são, na verdade, bactérias carregando a proteína sintetizada pelo artista, que revela-se um verdadeiro microcosmo. Também fazendo parte da obra, encontra-se, nas paredes do espaço expositivo, o trecho da narrativa bíblica escolhido pelo artista e a codificação em bases protéicas do DNA, proveniente do referido código Morse,traduzido por ele.

A antiga iconografia cristã e a reconstituição, adaptada ao presente, é o mote de uma série de vídeos e videoinstalações de Bill Viola, cujas obras, de acordo com Rush (2006), têm um forte apelo ao lirismo na arte. Desde o início dos anos 1970, ele cria uma grande variedade de instalações e vídeos. Ele próprio descreve seus trabalhos como "poemas visuais", nos quais aborda questões de identidade e significância espiritual no mundo moderno. Suas explorações de luz e forma estão geralmente aliadas aos seus interesses por assuntos de ordem espiritual. Em Stations (Estações), uma videoinstalação, imagens são projetadas em lajes verticais de granito que, por sua vez, refletem-se em lajes espelhadas colocadas no piso, perpendiculares às de granito. Corpos parecem cair no ar ou tombar na água nessa interpretação da Via Sacra.

Embora Viola use, nas suas instalações, equipamentos de vídeo e computador de alta tecnologia, os temas por ele explorados fazem parte de narrativas míticas e espirituais.

A beleza simples, o impacto visceral, a eterna espiritualidade atemporal do seu trabalho nos sensibiliza profundamente. Seu trabalho está embalado num conjunto de valores espirituais, os quais têm influência do zen-budismo, do misticismo cristão, da ótica física, dos mecanismos de percepção e da poesia islâmica dos mestres Sufi. Sua arte alcança as origens do conhecimento que reside no âmbito da experiência cotidiana. (ROSS apud WANNER, 2010, p. 253)

Os procedimentos contemporâneos utilizados por Viola chamam atenção pelas estratégias usadas para fazer referência à narrativa bíblica, indo além da pura representação. Para chegar aos resultados obtidos, foram envolvidas etapas de ressignificação da narrativa, estabelecendo uma correlação entre a obra e o tema que resguardam polissemias, metáforas, analogias e abstrações.

8 Placa de Petri: espécie de lâmina ou recipienteraso convenientemente preparado com um meio de cultura para aí se cultivarem microorganismos. 
Nas obras do norte americano James Turrel, o espectador é encerrado em ambientes a fim de controlar a sua percepção da luz. Os trabalhos de Turrell são destinados a serem vistos lenta e silenciosamente ao longo do tempo.

Pertencente, desde criança, à denominação religiosa dos Quakers, ${ }^{9}$ seus trabalhos possuem um forte apelo espiritual. Lembrando sua formação religiosa, Turrell (apud NOEVER, 2001, p. 78, tradução nossa) conta que o seu interesse inicial em luz inspirou-se em sua primeira experiência religiosa na Casa de Reunião Quaker. "Minha avó havia me levado ao culto e, ao final, me perguntou o que eu havia feito ali", diz ele, "esperando a minha resposta que não veio, ela mesma me disse: - você entrou para saudar a luz".

A Casa de Reunião Quaker, projetada por James Turrell, tem sido também palco de inúmeras sessões de meditação. Como obra artística, recebe anualmente milhares de visitas. A experiência no interior do espaço varia em diferentes épocas do ano e horários diferentes do dia. Essa obra constitui-se de uma sala fechada com capacidade para aproximadamente 15 pessoas. No interior do pequeno templo, as pessoas sentam em bancos de madeira para ver o céu através de uma abertura no teto, permitindo que aqueles que entram no espaço tenham uma experiência intimista com a luz, cuja noção assume uma conotação decididamente religiosa.

O trabalho de Turrell envolve a exploração do espaço e da luz, afetando, segundo Barros (2002), o olho, o corpo e a mente com a força de um despertar espiritual.

As pessoas falam de espiritual na arte, e eu acho que este foi o território de artistas o tempo todo. Em grandes catedrais feitas por arquitetos e através dos artesãos da luz, eles criaram um sentimento de temor que, muitas vezes, é maior do que as pessoas sentem quando leem, ou qualquer tipo de retórica do sacerdócio. Isso é algo muito poderoso em termos visuais. Os artistas sempre estiveram envolvidos nesta relação com o sagrado, o que não é algo novo. Eu acho que às vezes é mais fácil para as pessoas uma abordagem que parte do espiritual através do visual do que com a religião organizada, e talvez isso seja verdade hoje. Arte e religião têm sido ligadas desde o início da história da arte. A Capela Sistina foi comissionada para criar um espaço público onde as pessoas possam vir e meditar sobre a religião usando a arte como um catalisador para fazê-lo. (TURREL apud NOEVER, 2001, p. 137)

9 Quaker é o nome dado a vários grupos religiosos com origem comum num movimento protestante britânico do século XVII. 
James Turrell passou décadas experimentando com a luz. Não apenas explora a luz como uma ideia intelectual, mas realmente a utiliza como seu material principal de trabalho. Fascinado por espaços celestes e ilusões de percepção, tem dedicado sua vida a capturar as propriedades da luz e os seus poderes para evocar a transcendência e o sublime. No deserto do Arizona, em uma cratera de um vulcão extinto, está o trabalho mais importante de Turrell, o Roden Crater. Em Noever (2001, p. 170), Turrel afirma: "Eu tinha esse pensamento de trazer o cosmos mais perto". Ele construiu uma espécie de observatório, no qual as pessoas, ao adentrarem, têm uma experiência de imersão através da luz celeste. Esse observatório inclui uma série de túneis e câmaras de abertura para o céu, incentivando os visitantes a se conectarem com o cosmo. É como se o observador, ao olhar para o céu, pudesse trazê-lo para a terra. Turrel construiu um templo para a luz. Sem dúvida, como afirmam vários teóricos, uma das mais importantes obras da arte contemporânea.

As obras de James Turrel parecem possuir uma força arquetípica, traduzida em forma de poética luminosa. O sentimento do sublime e do transcendente, provocado por seus trabalhos, juntamente com a força evocada pelos materiais constitutivos da luz, reflete, de certa forma, a experiência vivenciada pelos ícones.

\section{Considerações finais}

Nos trabalhos realizados por esses artistas, é como se houvesse a tentativa de densificar a energia mítica arquetípica e volatilizar a matéria densa. Como nos diz Ana Amélia Bulhões (2003):

A arte abre-se à falta imanente ao ser humano, em sua impossibilidade de responder a questões como: De onde vim e para onde vou? O que faço aqui? Através delas, os indivíduos tentam construir socialmente, em seu imaginário, formas de ocupação desse vazio primordial, trabalhando sempre em um espaço dinâmico de fechamento e abertura. (BULHÕES, 2003, p. 59)

Ao contrário do que se pensa, muitos artistas modernos e contemporâneos têm revisitado temas sacros e utilizado desse mote como conceito, inserido através dos mais diversos tipos de materiais e técnicas. Especificamente, a narrativa bíblica tem sido utilizada por diversos artistas que se interessam por sua abordagem histórico-poética ao longo da história. Longe de estar ultrapassada ou esgotada, a sua narrativa ainda continua alimentando o imaginário de diversos artistas que reafirmam um dos maiores alicerces da mitologia ocidental na acepção do mito sacro como algo que transcende ao conhecimento racional, como uma 
verdade maior, além da nossa capacidade de entendimento convencional, cujo elo entre o material e o espiritual é a experiência estética singular do indivíduo.

\section{Referências}

BIBLIA. Português. Biblia de estudo Pentecostal. Tradução de João Ferreira Almeida. Flórida: Life Publishers, 1995.

AMARAL, L. Do espiritual na arte abstrata e na arte do informe em particular. In: AMARAL, L.; GEIGER, A. (Org.). In vitro, in vivo, in silício: ensaios sobre a relação entre arte, ciência, tecnologia e o sagrado. São Paulo: Attar, 2007. p. 191-233.

BARROS, A. Arte: um tecido de luz. In: BARROS, A.; SANTAELLA, L. (Org.). Midias e artes: os desafios da arte no início do século XXI. São Paulo: Unimarco, 2002. p. 33-58.

BENJAMIN, W. Sobre arte, técnica, linguagem e politica. Lisboa: Relógio D’Água, 1992.

BESANÇON, A. A imagem proibida: uma história intelectual de iconoclastia. Rio de Janeiro: Bertrand Brasil, 1997.

BULHÕES, M. A. O imaginário da arte: mitos e ritos na contemporaneidade. Cultura Visual. Salvador, v. 1, n. 5, p. 57-63, 2003.

BURKE, P. Uma história social da mídia. Rio de Janeiro: Jorge Zahar, 2004.

BURCKHARDT, T. A arte sagrada no Oriente e no Ocidente. São Paulo: Attar, 2004.

CAUQUELIN, A. Freqüentar os incorporais. São Paulo: Martins Fontes, 2008.

COUTO, S. P. A incrivel história da Bíblia. São Paulo: Universo dos Livros, 2007.

DANTO, A. C. A transfiguração do lugar comum. São Paulo: Cosac Naify, 2005.

ELIADE, M. O mito do eterno retorno. São Paulo: Edições 70, 1999.

FISCHER, H. Miranálise da arte. In: AMARAL, L.; GEIGER, A. (Org.). In vitro, in vivo, in silicio: ensaios sobre a relação entre arte, ciência, tecnologia e o sagrado. São Paulo: Attar, 2007. p. 337-357.

NOEVER, P. James Turrell: the other horizon. New Work: Hatje Cantz, 2001.

SANTIAGO-RAMOS, L. Pequena história do mal: Anselm Kiefer e Walter Benjamin. 2009, 363 f. Tese (Doutorado em Filosofia) - Faculdade de Filosofia, Letras e Ciências Humanas, Universidade de São Paulo, São Paulo, 2009.

SUSIN, L. C. Deus: Pai, Filho e Espírito Santo. São Paulo: Paulinas, 2003.

TOMASULA, S. (Gene)sis. In: AMARAL, L.; GEIGER, A. (Org.). In vitro, in vivo, in silício: ensaios sobre a relação entre arte, ciência, tecnologia e o sagrado. São Paulo: Attar, 2007. p. 309-320.

WANNER, M. C. de A. Paisagens sígnicas: uma reflexão sobre as artes visuais contemporâneas. Salvador: EDUFBA, 2010.

WOLF, N. Fé cristã e autonomia da razão (entrevista). Cult: Revista Brasileira de Cultura, São Paulo, v. 6, n. 64, p. 20-21, dez. 2002. 